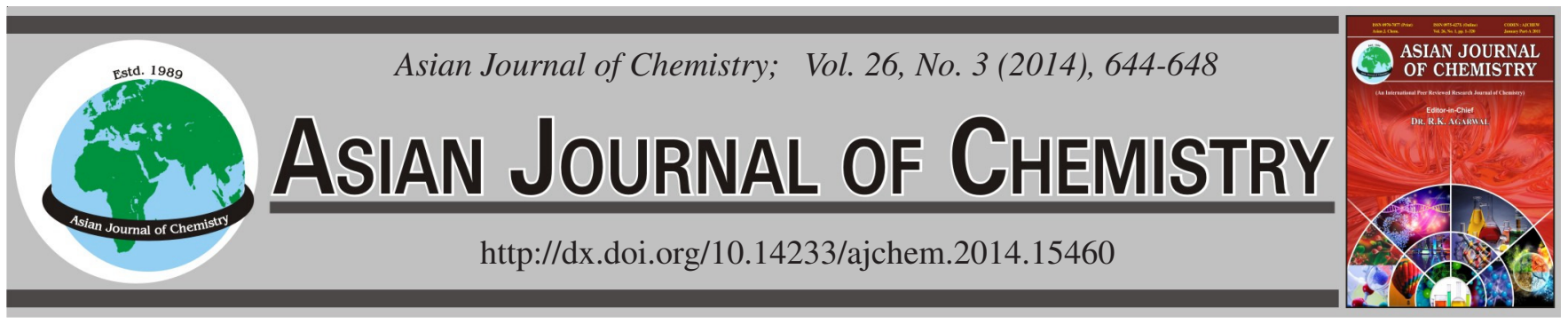

\title{
Adsorptive Elimination of Chromium(III) and Nickel(II) from Water by Spent Eugenia jambolana Leaves: Isothermal and Thermodynamical Studies
}

\author{
Rabia Rehman ${ }^{*}$, Jamil Anwar and TARiQ Mahmud
}

Institute of Chemistry, University of the Punjab, Lahore-54590, Pakistan

*Corresponding author: Fax: +92 42 99230998; Tel: +92 42 99230463, Ext: 870; E-mail: grinorganic@yahoo.com

Removal of metal ions from waste-water streams is a hot issue for environmental protection. In this study, adsorption capacity of spent Eugenia jambolana leaves was investigated for removing chromium(III) and nickel(II) from aqueous medium. FT-IR and chemical characterization of Eugenia jambolana leaves helps to investigate the mechanism of adsorption. Adsorption parameters were optimized and isothermal studies were carried out. It indicated that chemisorption mode is more predominant over physiosorption of $\mathrm{Ni}$ (II) and $\mathrm{Cr}$ (III) with maximum adsorption capacity 6.003 and $3.815 \mathrm{mg} / \mathrm{g}$, respectively. Feasibility of process is confirmed by separation factor values: 0.25 and 0.141 for $\mathrm{Ni}(\mathrm{II})$ and $\mathrm{Cr}$ (III) correspondingly and Gibb's free energy values: -6.971 and $-5.212 \mathrm{KJ} / \mathrm{mol}$ for $\mathrm{Ni}(\mathrm{II})$ and $\mathrm{Cr}(\mathrm{III})$, respectively. Heats of adsorption for $\mathrm{Ni}$ (II) and $\mathrm{Cr}$ (III) removal by Eugenia jambolana leaves were $-1.349 \mathrm{and}-0.0384 \mathrm{KJ} / \mathrm{mol}$, respectively. The results shown that Eugenia jambolana leaves can be used on industrial scale for removal of heavy metals.

Keywords: Chromium(III), Nickel(II), Eugenia jambolana leaves, Biosorption, Isothermal studies.

\section{INTRODUCTION}

Wastewater treatment for removing toxic metals is done usually by chemical precipitation, cation exchange, membrane filtration,reverse osmosis and biosorption ${ }^{1-3}$. The last one is studied vastly in last two decades by several scientists all over the world. Biosorption is basically a process of eradication of toxic substances by passive transfer to biosorbent from solution. It is extensively exploited as an alternative to traditional methods of removing and recovering of metals ${ }^{4,5}$. Cell immobilization of biomass before using for biosorption, improved its tensile strength, recycling, stability and the ease of handling. Researchers are trying waste materials from agricultural or industrial sources, having good adsorption capacity, low cost nature and availability for this purpose. Some examples are plant leaves, wheat husk, rice husk, bagasse, mango peels, banana peels, fly ash, maple sawdust, sewage waste etc $^{6-10}$.

In this work, spent leaves of Eugenia jambolana are used for removing chromium(III) and nickel(II) from water. Eugenia jambolana (other names: Syzygium jambolanum, Syzygium cumini,Pompozia, Jamun, black plum) belongs to Myrtaceae family of plants, evergreen tropical tree, grows largely all over Asian and African countries. Its bark and seeds are used in Ayruvedic medicines. Its nut and leaves are reported to have adsorption potential for removing toxic substances like lead(II), cadmium(II), mercury (II), chromium(VI) and Brilliant green dye $\mathrm{e}^{11-14}$.
The metals selected for study here are chromium(III) and nickel(II). These are essential elements for various biological activities of organisms like $\mathrm{Cr}$ (III) is important for sugar and lipid metabolism, whereas $\mathrm{Ni}(\mathrm{II})$ is essential for increasing iron absorption and treating osteoporosis. It is found in nucleic acids, where it is involved in protein structure development. It also supports the production of prolactin which is essential for mammals breast milk production. But excess quantity of $\mathrm{Cr}(\mathrm{III})$ and $\mathrm{Ni}$ (II) is toxic leading to various diseases e.g., nickel dermatitis allergy, carcinogenic and mutagenic activities, skin rashes, bronchitis, etc. They are usually found in waste water streams of electroplating activities, steel foundries, printing, batteries, vehicle industries, porcelain and chemical industries ${ }^{15-19}$. Permissible limits of $\mathrm{Cr}(\mathrm{III})$ and $\mathrm{Ni}(\mathrm{II})$ are 0.05 and $0.5 \mathrm{mg} / \mathrm{L}$, respectively, in drinking water ${ }^{20,21}$. So their removal from waste streams is crucial before discharging them into main water reservoirs.

\section{EXPERIMENTAL}

$\mathrm{CrCl}_{3} \cdot 6 \mathrm{H}_{2} \mathrm{O}, \mathrm{NiSO}_{4} \cdot 6 \mathrm{H}_{2} \mathrm{O}, \mathrm{HCl}, \mathrm{NaOH}$ and $\mathrm{NaCl}$ were obtained from Merck (Germany). Atomic absorption spectrometer (Perkin Elmer AAnalyst 100, equipped with airacetylene burner) and FT-IR spectrometer (Perkin Elmer RXI) were used.

Biosorbent preparation and characterization: Eugenia jambolana leaves (EGL) were collected from home institute. 
They were washed and dried in sunlight for 4-7 days and then in oven at $70{ }^{\circ} \mathrm{C}$ for $4 \mathrm{~h}$. Then they were ground and sieved through 60 mesh (ASTM). The fine powder was stored in plastic bottles after labeling, till further use. FT-IR spectrum of Eugenia jambolana leaves powder was recorded for surface characterization and resulting vibrational frequencies of specific functional groups were analyzed and presented in Table-1. Various physiochemical parameters like carboxylic acid content, lactones and basic sites contents (by Boehm titration), moisture contents, $\mathrm{pH}$, ash content and iodine number were determined using standard methods as described by Ekpete and Horsfall ${ }^{22}$ (Table-2).

\begin{tabular}{|c|c|}
\hline \multicolumn{2}{|c|}{$\begin{array}{c}\text { TABLE-1 } \\
\text { CHARACTERISTIC FT-IR FREQUENCIES OF } \\
\text { Eugenia jambolana LEAVES }\end{array}$} \\
\hline Functional groups assignment & Band frequencies $\left(\mathrm{cm}^{-1}\right)$ \\
\hline$v(\mathrm{~N}-\mathrm{H})$ & $3291(\mathrm{~m}), 1612(\mathrm{~m})$ \\
\hline$v(\mathrm{C}-\mathrm{H})$ of $-\mathrm{CHO}$ & 2917 (w) \\
\hline$v(\mathrm{O}-\mathrm{H})$ & $1023(\mathrm{~m})$ \\
\hline$v(-\mathrm{NCS}),(-\mathrm{NCO})$ or $(-\mathrm{CN})$ & $2354.3(w)$ \\
\hline$v(\mathrm{C}=\mathrm{O})$ & $1241.6(\mathrm{~s})$ \\
\hline$v(C-N)$ & $1023(\mathrm{~m})$ \\
\hline
\end{tabular}

TABLE-2

PHYSIOCHEMICAL ANALYSIS OF Eugenia jambolana LEAVES

\begin{tabular}{lc}
\hline \multicolumn{1}{c}{ Physiochemical parameters } & Quantification \\
\hline Carboxylic (acidic function) (mmol) & 1.986 \\
Phenol (mmol) & 0.003 \\
Lactones (mmol) & 0.001 \\
Basic sites (mmol) & 1.98 \\
$\mathrm{pH}$ & 5 \\
Iodine value $\left(\mathrm{mg} \mathrm{g}^{-1}\right)$ & 8.37 \\
Moisture contents $(\%)$ & 7.0 \\
Ash contents $(\%)$ & 6.1 \\
Volatile organic components $(\%)$ & 27.6 \\
Bulk density $\left(\mathrm{g} / \mathrm{cm}^{3}\right)$ & 0.895 \\
Dry density $\left(\mathrm{g} / \mathrm{cm}^{3}\right)$ & 0.292 \\
\hline
\end{tabular}

Synthetic waste water preparation and analysis of metal ions: Stock solutions (1000 mg/L) of $\mathrm{Cr}$ (III) and $\mathrm{Ni}(\mathrm{II})$ were made separately by mixing $3.03 \mathrm{~g}$ of $\mathrm{CrCl}_{3} \cdot 6 \mathrm{H}_{2} \mathrm{O}$ and $5.08 \mathrm{~g}$ of $\mathrm{NiSO}_{4} \cdot 6 \mathrm{H}_{2} \mathrm{O}$ in small amount of de-ionized water and diluting up to $1 \mathrm{~L}$. Further they were diluted according to the requirements of experimental conditions.

Adsorption studies: Different parameters were investigated by varying adsorbent amount (0.2-1.8 g), contact time, (10-90 min), initial $\mathrm{pH}$ of solution (1-8), agitation speed (50$250 \mathrm{rpm})$ and temperature $\left(20-70^{\circ} \mathrm{C}\right)$ using $50 \mathrm{~mL}$ of $50 \mathrm{ppm}$ $\left(\mathrm{C}_{\mathrm{o}}\right)$ metal ion solutions (V) separately, at $25 \pm 1{ }^{\circ} \mathrm{C}$. $\mathrm{pH}$ was adjusted with $0.01 \mathrm{M} \mathrm{HCl} / \mathrm{NaOH}$ according to requirement using $\mathrm{pH}$ meter (HANNA pH 211). After each experiment, solutions were filtered and remaining metal ions ' $\mathrm{C}_{\mathrm{e}}$ ' concentration was determined by AAS working at $357.9 \mathrm{~nm}$ for chromium and for nickel at $232 \mathrm{~nm}$. For isothermal studies, stock solutions of $\mathrm{Cr}$ (III) and $\mathrm{Ni}$ (II) were diluted in range of 30-80 ppm separately and optimized conditions of all above parameters were applied correspondingly ${ }^{23}$.

Mathematical data evaluation: The percentage removal of metal ions was determined by eqn. 1 :

$$
\text { Removal of metal ions }(\%)=\frac{\mathrm{C}_{\mathrm{o}}-\mathrm{C}_{\mathrm{e}}}{\mathrm{C}_{\mathrm{o}}} \times 100
$$

Langmuir parameters were calculated by regression analysis of eqn. 2:

$$
\frac{1}{\mathrm{q}}=\frac{1}{\mathrm{bq}_{\mathrm{m}} \mathrm{C}_{\mathrm{e}}}+\frac{1}{\mathrm{q}_{\mathrm{m}}}
$$

Freundlich parameters were calculated by regression analysis of eqn. 3:

$$
\log \mathrm{q}=\log \mathrm{K}_{\mathrm{F}}+\frac{1}{\mathrm{n}} \log \mathrm{C}_{\mathrm{e}}
$$

Temkin parameters were calculated by regression analysis of eqn. 4:

$$
\mathrm{q}=\mathrm{B}_{\mathrm{T}} \ln \mathrm{C}_{\mathrm{e}}+\mathrm{B}_{\mathrm{T}} \ln \mathrm{K}_{\mathrm{T}}
$$

Adsorption capacity 'q'was determined by eqn. 5 :

$$
\begin{aligned}
& q=\frac{\left(C_{o}-C_{e}\right) V}{m} \\
& R_{L}=\frac{1}{\left(1+b C_{o}\right)}
\end{aligned}
$$

Thermodynamic parameter $2 \Delta \mathrm{G}^{\mathrm{o}}$, was determined by eqn. 7:

$$
\Delta \mathrm{G}^{\mathrm{o}}=-\mathrm{RT} \ln \mathrm{K}
$$

In these equations, ' $\mathrm{q}$ ' ( $\mathrm{mg} / \mathrm{g})$ is the amount of metal ions removed by Eugenia jambolana leaves, ' $\mathrm{q}_{\mathrm{m}}$ ' (mg/g) and b $(\mathrm{L} / \mathrm{g})$ are Langmuir parameters, ' $\mathrm{K}_{\mathrm{F}}$ ' $\left(\mathrm{mg}^{1-1 / \mathrm{n}} \mathrm{L}^{1 / \mathrm{n}} \mathrm{g}^{-1}\right)$ and ' $\mathrm{n}$ ' are Freundlich constants, heat of adsorption is ' $\mathrm{B}_{\mathrm{T}}$ ' $=\mathrm{RT} / \mathrm{b}$, ' $\mathrm{T}$ ' is temperature (Kelvin), ' $\mathrm{R}$ ' is gas constant $(8.314 \mathrm{~J} / \mathrm{mol})$, ' $\mathrm{K}_{\mathrm{T}}$ ' is the equilibrium binding constant $(\mathrm{L} / \mathrm{mg}),{ }^{\prime} \Delta \mathrm{G}^{\mathrm{o}}$ ' is Gibb's free energy $(\mathrm{KJ} / \mathrm{mol})$ and ' $\mathrm{K}$ ' $=1 / \mathrm{b}^{24-29}$.

\section{RESULTS AND DISCUSSION}

Surface characterization of Eugenia jambolana leaves: FT-IR analysis of Eugenia jambolana leaves revealed that it contains several functional groups e.g., - $\mathrm{OH},-\mathrm{CO},-\mathrm{NH}$ and $-\mathrm{COOH}$ that can act as possible adsorption sites (Table-1). The bands at $2917 \mathrm{~cm}^{-1}$ were due to methylene $\left(-\mathrm{CH}_{2}-\mathrm{CH}_{2}-\right)$ group stretching vibrations. The band at $1242 \mathrm{~cm}^{-1}$ was ascribed to ester, ethers and/or phenol groups. Vibrational peaks between 2300-2000 $\mathrm{cm}^{-1}$ was assigned to -NCS, -NCO or $-\mathrm{CN}^{14}$. Physio-chemical analysis of Eugenia jambolana leaves given in Table-2 showed decreased levels of moisture, ash and volatile matter contents, demonstrating that the particle density is quite small and this biomaterial should be an efficient raw material as an adsorbent. Iodine value is indicating that sufficient amount unsaturated compounds are present in Eugenia jambolana leaves. The type/concentration of surface functional groups of Eugenia jambolana leaves were found by the Boehm titration procedure. Strongly acidic carboxylic sites are neutralized by $\mathrm{NaHCO}_{3}$, whereas those neutralized by $\mathrm{Na}_{2} \mathrm{CO}_{3}$ are thought to be lactonic and carboxylic sites which can bind metal ions during adsorption process. The weakly acidic phenolic sites only react with $\mathrm{NaOH}$. Surface basic group's pyrones and chromenes were neutralized by $\mathrm{HCl}$, which can chelate metal ions ${ }^{22}$. 
Adsorption parameters optimization: Batch adsorption process had been carried out for the removal of $\mathrm{Ni}$ (II) and $\mathrm{Cr}$ (III) by Eugenia jambolana leaves as an adsorbent. By utilizing the adsorption properties of Eugenia jambolana leaves these heavy metals had been removed from their aqueous solution and different parameters had been studied. Adsorption is a complex phenomenon in which metallic species can be deposited on Eugenia jambolana leaves through various process e.g. complexation, ion-exchange, precipitation, chelation etc. The rapid uptake of $\mathrm{Cr}$ (III) and $\mathrm{Ni}$ (II) from their aqueous solution has suggested that the metal binding has occurred due to cell wall structure of the Eugenia jambolana leaves and not due to any cellular process, because it is dependent on chemical make-up of cell wall and not on metabolic activities within plant cells.

Fig. 1 shows that in the case of $\mathrm{Cr}$ (III) adsorption increases with an increase in adsorbent amount to some extent and after reaching equilibrium it became constant whereas in the case of $\mathrm{Ni}$ (II) the adsorption decreases after the equilibrium has been established. For $\mathrm{Cr}$ (III) minimum adsorption the dose of $1.4 \mathrm{~g}$ to maximum adsorption value of $80.16 \%$ for dose of $0.6 \mathrm{~g}$. For Ni(II) minimum adsorption was $77.44 \%$ for the dose of $0.2 \mathrm{~g}$ to maximum adsorption value of $86.86 \%$ for dose of $0.8 \mathrm{~g}$. More adsorption sites are vacant at the beginning, so adsorption rate increases gradually, then decreases. It is also observed that adsorption with high dose of adsorbent need less time interval to reach equilibrium.

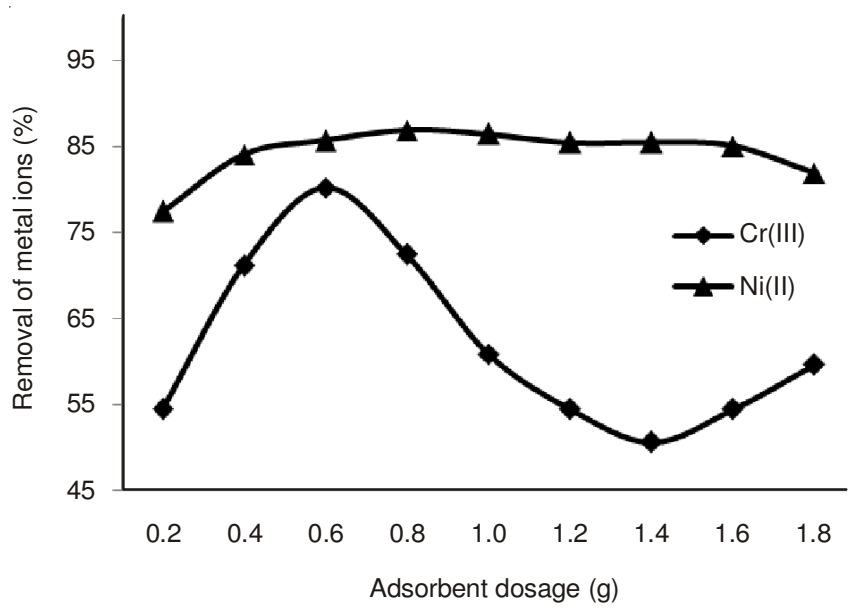

Fig. 1. Adsorbent dose effect on $\mathrm{Cr}(\mathrm{III})$ and $\mathrm{Ni}$ (II) adsorptive removal from water by Eugenia jambolana leaves

Fig. 2 shows the effect of contact time on adsorption for $\mathrm{Cr}$ (III) and $\mathrm{Ni}$ (II). For Cr(III), minimum removal was $59.56 \%$ for contact time of $5 \mathrm{~min}$ and maximum removal was $84.03 \%$ for contact time of $25 \mathrm{~min}$. For Ni(II) minimum removal was $77.64 \%$ for the time of $5 \mathrm{~min}$ and maximum removal was $90.47 \%$ for contact time of $15 \mathrm{~min}$. In start of adsorption process, removal occurs rapidly as soon as metal ions and biosorbent came into contact, because metal ions have more time for making complex with it. But after that metal ions needs time for finding out more active sites for binding ${ }^{27,28}$.

Fig. 3 showed that $\mathrm{pH}$ affects adsorption processes of metal ions considerably. As the $\mathrm{pH}$ rises, removal efficiency of adsorbent increases and the best results are obtained at $\mathrm{pH}$

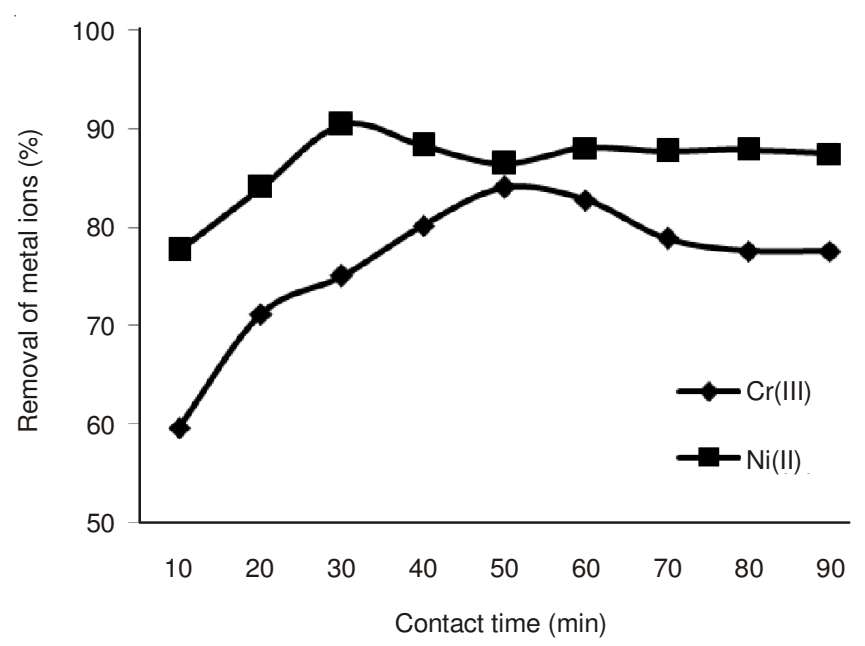

Fig. 2. Contact time effect on $\mathrm{Cr}$ (III) and $\mathrm{Ni}(\mathrm{II})$ adsorptive removal from water by Eugenia jambolana leaves

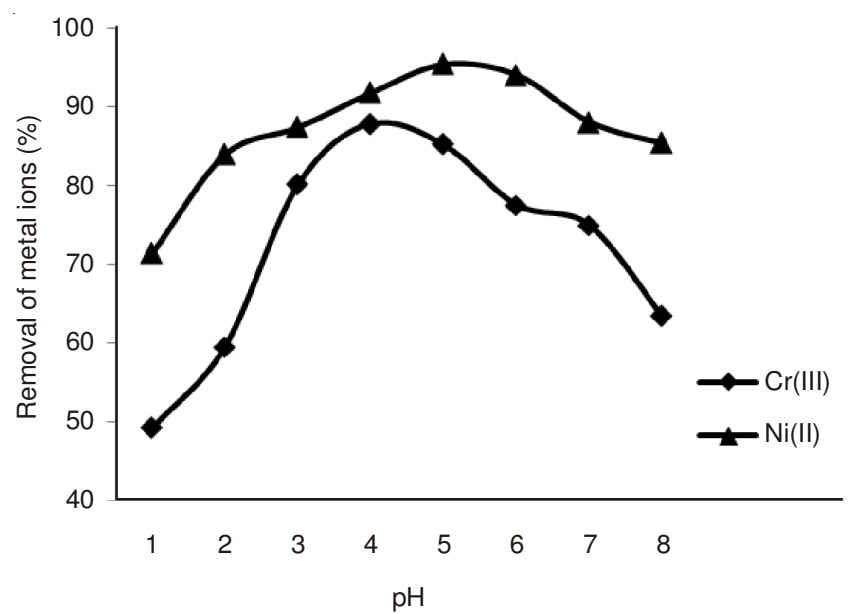

Fig. 3. Solution $\mathrm{pH}$ effect on $\mathrm{Cr}(\mathrm{III})$ and $\mathrm{Ni}(\mathrm{II})$ adsorptive removal from water by Eugenia jambolana leaves

$=4$. For $\mathrm{Cr}(\mathrm{III})$, minimum removal was $49.25 \%$ at $\mathrm{pH}=1$ and maximum removal was $87.89 \%$ at $\mathrm{pH}=4$ i.e., the adsorption takes place in acidic media. It is found that at $\mathrm{pH}$ lower than 4 ; chromium removal is inhibited possibly as a result of competition between hydrogen and $\mathrm{Cr}(\mathrm{III})$ ions. For Ni(II), optimum adsorption occurred at $\mathrm{pH}=5$ i.e., in acidic media. Minimum removal was $71.43 \%$ at $\mathrm{pH}=1$ and maximum removal efficiency was $95.48 \%$ at $5 \mathrm{pH}$. Adsorption takes place as the carboxyl functional groups are deprotonated and provide active sites for the binding of metal ions. At high $\mathrm{pH}$ (greater than 8.5), precipitation occurred due to the formation of hydroxides, making accurate sorption studies difficult.

Effect of agitation speed on adsorptive removal of metal ions by Eugenia jambolana leaves was shown in Fig. 4. By increasing shaking speed, adsorption increases. If it is slow, the adsorbent accumulates instead of spreading in solution and binding sites are buried under the above layers of adsorbent powder. So adsorption occurs by above layers and suppressed layers do not involve in it. Increase in adsorption with agitation speed is also due to the fact that adsorbent is thoroughly mixed in water at high speed and as a result more metal ions and adsorbent came into contact due to formation of very fine suspension and thus, removal efficiency increases. The minimum 
TABLE-3

LANGMUIR PARAMETERS FOR Cr(III) AND Ni(II) ADSORPTIVE REMOVAL FROM WATER BY Eugenia jambolana LEAVES

\begin{tabular}{cccccccc}
\hline Metal ions & Slope & Intercept & $\mathrm{R}^{2}$ & $\mathrm{q}_{\max }(\mathrm{mg} / \mathrm{g})$ & $\mathrm{b}(\mathrm{L} / \mathrm{g})$ & $\mathrm{R}_{\mathrm{L}}$ & $\Delta \mathrm{G}^{\mathbf{0}}(\mathrm{KJ} / \mathrm{mol})$ \\
\hline $\mathrm{Ni}(\mathrm{II})$ & 2.153 & 0.262 & 0.987 & 6.003 & 0.060 & 0.25 & -6.971 \\
$\mathrm{Cr}(\mathrm{III})$ & 2.769 & 0.167 & 0.982 & 3.815 & 0.122 & 0.141 & -5.212 \\
\hline
\end{tabular}

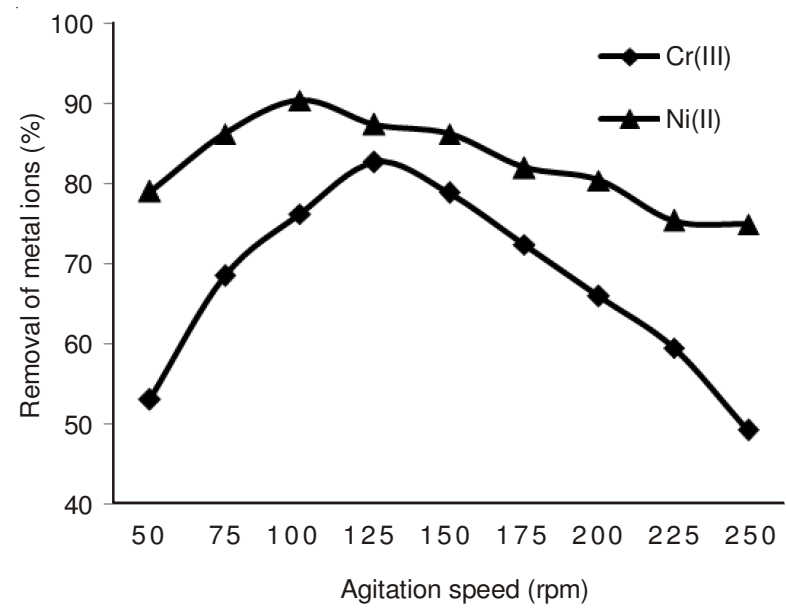

Fig. 4. Agitation effect on $\mathrm{Cr}(\mathrm{III})$ and $\mathrm{Ni}(\mathrm{II})$ adsorptive removal from water by Eugenia jambolana leaves

removal of $\mathrm{Cr}$ (III) was $49.25 \%$ at $250 \mathrm{rpm}$ and maximum removal was $82.74 \%$ at $125 \mathrm{rpm}$. This indicates that shaking rate should be satisfactory for ensuring that entire adsorption sites are made readily available for $\mathrm{Cr}$ (III) uptake. For $\mathrm{Ni}(\mathrm{II})$, minimum removal was $75.04 \%$ at $250 \mathrm{rpm}$ and maximum removal was $90.47 \%$ at $100 \mathrm{rpm}$. So, agitation speed of 125 and $100 \mathrm{rpm}$ were found optimum for both $\mathrm{Cr}(\mathrm{III})$ and $\mathrm{Ni}(\mathrm{II})$ removal, respectively by Eugenia jambolana leaves. But at greater speed, removal efficiency of Eugenia jambolana leaves decreased as less contact occurred between metal ion solution and adsorbent ${ }^{29}$.

Temperature effects adsorption processes, because they are usually endothermic. Using agro-waste material, this factor gains more importance, because at higher temperature degradation of biopolymers present in plant materials occurred. Sometimes it is beneficial, as more adsorption sites are created, but usually it is not favorable, because it decreases shelf life of biosorbent ${ }^{17-19}$. Fig. 5 is showed that the maximum adsorption of $\mathrm{Cr}(\mathrm{III})$ occurred at $40{ }^{\circ} \mathrm{C}$ and of $\mathrm{Ni}(\mathrm{II})$ at $30^{\circ} \mathrm{C}$.

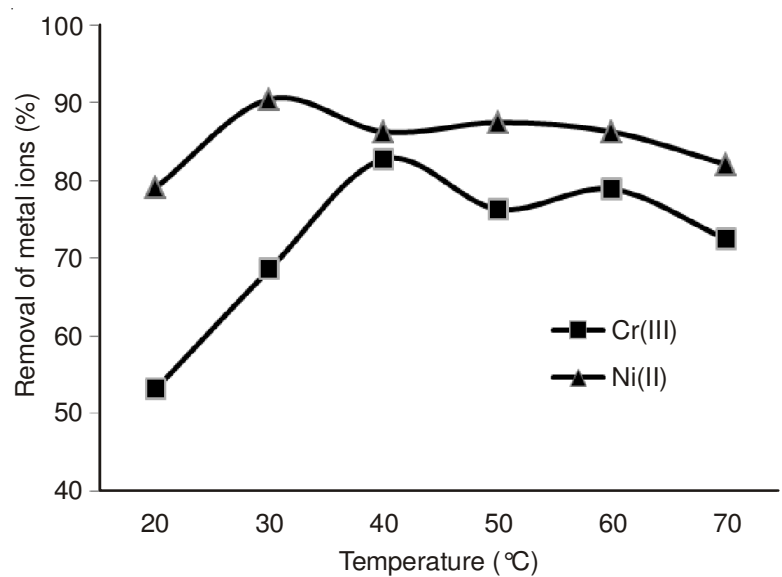

Fig. 5. Temperature effect on $\mathrm{Cr}(\mathrm{III})$ and Ni(II) adsorptive removal from water by Eugenia jambolana leaves
Isothermal and mechanistic studies: For determining mechanism of adsorption, isothermal parameters are investigated using three models, namely: Langmuir, Freundlich and Temkin and their respective values are tabulated in Tables $3-5$, respectively. Comparison of correlation coefficient ' $\mathrm{R}^{2}$, values indicated that Freundlich parameters is more followed by both metal ions, as compared to other two models, indicating that multilayer physiosorption occurred more as compared to monolayer chemisorption. Maximum adsorptive removal of $\mathrm{Ni}$ (II) and $\mathrm{Cr}$ (III) are 6.003 and $3.815 \mathrm{mg} / \mathrm{g}$ of Eugenia jambolana leaves (EGL). Comparing these values with other reported adsorbent values indicated that Eugenia jambolana leaves has great potential to be used as adsorbent, as clear from Table-6. Langmuir isotherm constant ' $\mathrm{b}$ '( $\mathrm{L} / \mathrm{g}$ ) values for $\mathrm{Ni}(\mathrm{II})$ and $\mathrm{Cr}$ (III) is: 0.060 and $0.1217 \mathrm{~L} / \mathrm{g}$. They were used to calculate separation factor values, $\mathrm{R}_{\mathrm{L}}$ and Gibb's free energy $\Delta \mathrm{G}^{\mathrm{o}}$. The $\mathrm{R}_{\mathrm{L}}$ values between 0-1 means favorable adsorption. Negative values of Gibb's free energy indicated the spontaneity of the process. Freundlich model constant 'n' values for $\mathrm{Ni}(\mathrm{II})$ and $\mathrm{Cr}$ (III) are 1.82 and 2.448, respectively. Temkin parameters $\mathrm{K}_{\mathrm{T}}$ values for $\mathrm{Ni}(\mathrm{II})$ and $\mathrm{Cr}(\mathrm{III})$; 1.556, 0.916; depicted satisfactory adsorption potential of Eugenia jambolana leaves. Also heat of sorption $\mathrm{B}_{\mathrm{T}}$ values were -1.349 and -0.0384 for $\mathrm{Ni}(\mathrm{II})$ and $\mathrm{Cr}(\mathrm{III})$ correspondingly suggested weak chemical interaction between metal ions and Eugenia jambolana leaves. The constants ' $\mathrm{n}$ ' and ' $\mathrm{B}_{\mathrm{T}}$ ' values lesser than 8 point out weaker interaction between metal ions and adsorbent, favoring physiosorption mode of adsorption ${ }^{25-29}$.

\begin{tabular}{cccccc}
\multicolumn{7}{c}{ TABLE-4 } \\
FREUNDLICH PARAMETERS FOR Cr(III) AND Ni(II) \\
ADSORPTIVE REMOVAL FROM WATER BY \\
Eugenia jambolana LEAVES \\
\hline $\begin{array}{c}\text { Metal } \\
\text { ions }\end{array}$ & Slope & Intercept & $\mathrm{R}^{2}$ & $\begin{array}{c}\mathrm{K}_{\mathrm{F}}\left(\mathrm{mg}^{1-1 / \mathrm{n}}\right. \\
\left.\mathrm{L}^{1 / \mathrm{n}} \mathrm{g}^{-1}\right)\end{array}$ & $\mathrm{n}$ \\
\hline Ni(II) & 0.549 & 0.204 & 0.995 & 0.625 & 1.82 \\
$\mathrm{Cr}(\mathrm{III})$ & 0.408 & 0.104 & 0.987 & 0.787 & 2.448 \\
\hline
\end{tabular}

\begin{tabular}{cccccc}
\multicolumn{6}{c}{ TABLE-5 } \\
& TEMKIN PARAMETERS FOR Cr(III) AND Ni(II) \\
& ADSORPTIVE REMOVAL FROM WATER BY \\
& \multicolumn{6}{c}{ Eugenia jambolana LEAVES } \\
\hline Metal ions & Slope & Intercept & $\mathrm{R}^{2}$ & $\mathrm{~B}_{\mathrm{T}}(\mathrm{KJ} / \mathrm{mol})$ & $\mathrm{K}_{\mathrm{T}}$ \\
\hline $\mathrm{Ni}(\mathrm{II})$ & 1.556 & 1.349 & 0.984 & -1.349 & 1.556 \\
$\mathrm{Cr}(\mathrm{III})$ & 0.916 & 0.0384 & 0.986 & -0.0384 & 0.916 \\
\hline
\end{tabular}

\section{Conclusion}

It is found that Eugenia jambolana leaves can efficiently remove $\mathrm{Cr}$ (III) and $\mathrm{Ni}$ (II) ions from water. Optimized conditions for $\mathrm{Cr}$ (III) are: $0.6 \mathrm{~g}$ adsorbent dose, 25 minutes contact time, $4 \mathrm{pH}, 125 \mathrm{rpm}$ agitation speed and $40{ }^{\circ} \mathrm{C}$ temperature, and for $\mathrm{Ni}(\mathrm{II})$ are: $0.8 \mathrm{~g}$ adsorbent dose, 15 min contact time, $5 \mathrm{pH}$, $100 \mathrm{rpm}$ agitation speed and $30^{\circ} \mathrm{C}$ temperature. Hence it is concluded that Eugenia jambolana leaves are the efficient 
TABLE-6

MAXIMUM ADSORPTION CAPACITY OF REPORTED ADSORBENTS FOR REMOVING Cr(III) AND Ni(II) FROM WATER ${ }^{17-29}$

\begin{tabular}{lc|lc}
\multicolumn{1}{c|}{$\mathrm{Cr}(\mathrm{III})$} & \multicolumn{1}{c}{$\mathrm{Ni}(\mathrm{II})$} \\
\hline \multicolumn{1}{c|}{ Adsorbent } & $\mathrm{q}_{\max }(\mathrm{mg} / \mathrm{g})$ & Adsorbent & $\mathrm{q}_{\max }(\mathrm{mg} / \mathrm{g})$ \\
\hline Poplar tree & 5.52 & Fly ash & 0.683 \\
Spruce & 0.30 & Granular activated carbon & 1.49 \\
Straw Sorghum & 6.96 & Cashew nut shell & 18.868 \\
Polyalthia longifolia leaves & 1.87 & Pinus sylvestris cone & 3.12 \\
Test of sea urchin & 15.46 & Aspergillus niger & 1.1 \\
Talinum triangulare (water leaf) & 40 & Rice hull & 5.58 \\
\hline
\end{tabular}

adsorbent, as these show high efficiency for the removal of $\mathrm{Cr}(\mathrm{III})$ and $\mathrm{Ni}(\mathrm{II})$ from aqueous solutions. The maximum adsorption capacity $\left(\mathrm{q}_{\max }\right)$ for $\mathrm{Ni}(\mathrm{II})$ and $\mathrm{Cr}(\mathrm{III})$ obtained from Langmuir isotherm is 6.0024 and 3.815 (mg of metal/g adsorbent). So, it is concluded that Eugenia jambolanaleaves are the efficient adsorbent for the removal of $\mathrm{Cr}$ (III) and $\mathrm{Ni}(\mathrm{II})$ from wastewater in the order $\mathrm{Ni}$ (II) $>\mathrm{Cr}$ (III). Freundlich adsorption isotherm model shows linearity for removal of both the metals indicating the multi-layer physiosorption is dominant over chemisorption. Thermodynamic values favour the spontaneity of process. So, Eugenia jambolana leaves can be effectively employed on larger scale metal ion removal from wastewater, as it is cheap and easily available from indigenous sources of Asian countries.

\section{REFERENCES}

1. A. Demirbas, J. Hazard. Mater., 157, 220 (2008).

2. D.W. O'Connell, C. Birkinshaw and T.F. O'Dwyer, Bioresour. Technol., 99, 6709 (2008).

3. A. García-Mendieta, M.T. Olguín and M. Solache-Ríos, Desalination, 284, 167 (2012).

4. M. Torab-Mostaedi, M. Asadollahzadeh, A. Hemmati and A. Khosravi, J. Taiwan Inst. Chem. E, 44, 295 (2013).

5. L.J. Yu, S.S. Shukla, K.L. Dorris, A. Shukla and J.L. Margrave, J. Hazard. Mater., 100, 53 (2003).

6. V.K. Gupta, C.K. Jain, I. Ali, M. Sharma and V.K. Saini, Water Res., 37, 4038 (2003).

7. D. Mohan, K.P. Singh and V.K. Singh, J. Hazard. Mater., 135, 280 (2006).

8. Y. Wu, S. Zhang, X. Guo and H. Huang, Bioresour. Technol., 99, 7709 (2008).

9. N.F. Fahim, B.N. Barsoum, A.E. Eid and M.S. Khalil, J. Hazard. Mater, 136, 303 (2006).
10. X.J. Zuo and R. Balasubramanian, Carbohydr. Polym., 92, 2181 (2013).

11. K.S. Rao, S. Anand and P. Venkateswarlu, J. Ind. Eng. Chem., 17, 174 (2011).

12. P. King, N. Rakesh, S. Beenalahari, Y. Prasanna Kumar and V.S.R.K. Prasad, J. Hazard. Mater., 142, 340 (2007).

13. K. Muthukumaran and S. Sophie Beulah, Asian J. Chem., 22, 7857 (2010).

14. R. Rehman, J. Anwar, T. Mahmud and M. Salman, J. Chem. Soc. Pak., 34, 136 (2012).

15. S.S. Tahir and R. Naseem, Sep. Purif. Technol., 53, 312 (2007).

16. S.S. Shukla, L.J. Yu, K.L. Dorris and A. Shukla, J. Hazard. Mater., 121, 243 (2005).

17. M. Gürü, D. Venedik and A. Murathan, J. Hazard. Mater, 160, 318 (2008).

18. K. Anoop Krishnan, K.G. Sreejalekshmi and R.S. Baiju, Bioresour. Technol., 102, 10239 (2011).

19. K. Sundar, I.M. Sadiq, A. Mukherjee and N. Chandrasekaran, J. Hazard. Mater., 196, 44 (2011).

20. K.G. Bhattacharyya, J. Sarma and A. Sarma, J. Hazard. Mater, 165, 271 (2009).

21. F. Kanwal, R. Rehman, T. Mahmud, J. Anwar and R. Ilyas, J. Chil. Chem. Soc., 57, 1058 (2012).

22. O.A. Ekpete and M.J.N.R. Horsfall, Res. J. Chem. Sci., 1, 10 (2011).

23. P. King, K. Anuradha, S.B. Lahari, Y. Prasanna Kumar and V.S.R.K. Prasad, J. Hazard. Mater., 152, 324 (2008).

24. P. Miretzky and A.F. Cirelli, J. Hazard. Mater, 180, 1 (2010).

25. J. Anwar, U. Shafique, Waheed-uz-Zaman, Z. un Nisa, M.A. Munawar, N. Jamil, M. Salman, A. Dar, R. Rehman, J. Saif, H. Gul and T. Iqbal, Int. J. Phytoremed., 13, 410 (2011).

26. V. Saradhi, S.R.K. Rao, Y.P. Kumar, P. Vijetha, K.V. Rao and G. Kalyani, Int. J. Chem. Eng. Res., 2, 139 (2010).

27. A. Kapoor and T. Viraraghavan, Bioresour. Technol., 63, 109 (1997).

28. K. Kadirvelu, K. Thamaraiselvi and C. Namasivayam, Sep. Purif. Technol., 24, 497 (2001).

29. M.Y. Can, Y. Kaya and O.F. Algur, Bioresour. Technol., 97, 1761 (2006). 